NBER WORKING PAPER SERIES

\title{
THE EUROPEAN CENTRAL BANK AND THE EURO: THE FIRST YEAR
}

\author{
Martin Feldstein \\ Working Paper 7517 \\ http://www.nber.org/papers/w7517 \\ NATIONAL BUREAU OF ECONOMIC RESEARCH \\ 1050 Massachusetts Avenue \\ Cambridge, MA 02138 \\ February 2000
}

This paper is an expanded version of remarks prepared for presentation at the annual meeting of the American Economic Association, January 8, 2000, and replaces both the initial version and the slightly revised version that was issued shortly after the meeting. This paper and the others that were presented at the American Economic Association session will be published in The Journal of Policy Modeling. The views expressed herein are those of the author and not necessarily those of the National Bureau of Economic Research.

(C) 2000 by Martin Feldstein. All rights reserved. Short sections of text, not to exceed two paragraphs, may be quoted without explicit permission provided that full credit, including (C) notice, is given to the source.

The European Central Bank and the Euro: The First Year 
Martin Feldstein

NBER Working Paper No. 7517

February 2000

JEL No. F33

\begin{abstract}
The creation of the euro and the European Central Bank is a remarkable and unprecedented event in economic and political history: creating a supranational central bank and leaving eleven countries without national currencies of their own. The experience of the first year confirms that "one size fits all" monetary policy is not suitable for Europe because cyclical and inflation conditions vary substantially among countries. Labor market policies during this first year will increase this problem in the future and may lead to more trade protectionism. The paper explores reasons why cyclical unemployment, structural unemployment, and inflation may all be higher in the future as a result of the single currency. Although some advocate the euro despite its economic problems because of its assumed favorable effects on European political cohesiveness, the paper argues that it is more likely to lead to political conflict within Europe and with the Unites States.
\end{abstract}

\author{
Martin Feldstein \\ President of the National Bureau of Economic Research \\ 1050 Massachusetts Avenue \\ Cambridge, MA 02138 \\ and Professor of Economics at Harvard University \\ msfeldst@nber.org
}


We are meeting today to commemorate the first anniversary of the creation of the euro, a remarkable and unprecedented event in economic and political history: the creation of a supernational currency that will, when it is fully implemented two years from now, leave the major nation's of Europe without any currencies of their own. Never before has a major country not had its own currency.

I say that we are here to commemorate rather than to celebrate this first birthday of the euro because I believe that the creation of the euro and of the European Economic and Monetary Union is at best an act of uncertain merit. As I have noted before ${ }^{1}$, the euro is likely to have adverse medium-term and long-term effects on employment and inflation and is likely to be the source of political conflicts within Europe and between Europe and the United States. If I am correct, this is certainly not a cause for celebration.

But whether it is for better or for worse, the introduction of the euro and its survival are remarkable events. There were many skeptics who thought it could not come into being. But in the end Germany agreed to abandon its own beloved currency in favor of the unknown euro and to open the new EMU club to countries that met the tests of membership only by heroic acts of accounting manipulation.

${ }^{1}$ See my articles "The Case Against EMU," The Economist, June 13, 1992; "The Political Economy of the European Economic and Monetary Union: Political Sources of an Economic Liability." Journal of Economic Perspectives , Fall 1997; and "EMU and International Conflict," Foreign Affairs, March-April 1998. 


\section{The First Year Record}

The eleven parents of the newborn child gathered a year ago to admire their offspring and to predict great things for its future. They declared that it would be a strong new player in the global economy, reflecting the size of the European market relative to that of the United States. They warned that the shift of global portfolios to euro assets would depress the value of the dollar relative to the euro.

Things have not quite worked out that way. The value of the euro has declined by about 15 percent during the year relative to the dollar and even more relative to the yen. The European economy remained weak and unemployment remained at more than twice the level in the United States. The counterproductive tax and social benefit policies, the excessive regulations, and the anti-business policies of the governments in both France and Germany have contributed to both of these poor measures of performance. These policies repelled foreign domestic investment and encouraged European firms to invest outside the euro area; both tendencies depressed the demand for the euro and therefore its value. Those same policies prevented a decline in unemployment rates by keeping wage costs uncompetitively high and reducing the incentive for individuals to seek work or to accept any but the best jobs.

It nevertheless remains true that this remarkable new and unprecedented currency did come into being and did survive the first year. Those who projected strength for the euro were concerned less with economic fundamentals than with political symbols. However the currency is not the flag and there is no reason to be unhappy that it fell in value, especially since that has helped to strengthen aggregate demand by increasing Europe's net exports and has done so without any obvious increase in overall inflation. 
The sharp fall of the euro relative to the dollar and to the yen are a clear reminder, however, that adoption of the euro did not bring exchange rate stability to European producers and consumers. While the exchange rate within the euro area is fixed, the exchange rate with other currencies can vary and may vary even more than it did before the adoption of the euro. For a German firm that uses oil or other inputs that are priced in dollars, the sharp decline of the euro has meant an equally sharp increase in the cost of production and a corresponding loss of competitiveness.

The survival of the euro occurred despite the antics of Oskar Lafontaine during his brief tenure as German Finance Minister. Mr. Lafontaine did not seem to understand the notion of an independent central bank and believed that the European Council of Economic and Finance Ministers (the ECOFIN) should play an important role in the making of monetary policy. He clearly believed that a more political monetary policy would mean an easier monetary policy and assumed that such a policy would lead to lower unemployment. Fortunately, the European Central Bank (ECB) made it clear that it would act independently and the other leading countries of the EMU did not follow the German rhetorical line. Even more fortunately, Mr. Lafontaine burned himself out quickly and vanished, at least temporarily, from the German political scene.

The European Central Bank is also to be praised for the professional way in which it managed the initial establishment of the euro in the international markets and the apparent smoothness of the interbank relations in its first year of operation.

The ECB was however less successful in communicating the nature of its monetary policy to a nervous financial system. Unlike the Bundesbank which always spoke in terms of a target growth rate for its monetary aggregate or the Bank of England with its explicit inflation 
target, the ECB has adopted a policy in which both money and inflation appear to be the targets by which monetary policy is guided. The fact that they are referred to as two "pillars" of monetary policy, rather than as two targets, does not clarify the situation. This seeming violation of Jan Tinbergen's first principle of instruments and targets leaves financial markets confused, an uncertainty that is compounded by the limited information that is revealed about the deliberations of the ECB and by the occasional tendency for the members of the ECB to speak in contradictory terms. It is exacerbated also by the apparent lack of agreement about the significance of the international value of the currency, with some members of the ECB more concerned about that value per se while others consider it important only to the extent that it influences the domestic price level. But perhaps these are teething problems of the newborn institution that will soon be outgrown.

The one major achievement that can probably be attributed to the creation of the euro is the expansion of the European commercial bond market. The ability to borrow and lend in euros and to do so without fear of exchange rate fluctuations between the borrower and the lender has facilitated substantial cross-border lending within the euro area. Whether this has had significant effects on the level of real interest rates or on economic production remains to be studied. It has undoubtedly made it easier to finance cross-border corporate takeovers, a development that has not generally been welcomed by the governments of the target companies.

The ECB also succeeded in 1999 in fostering a strengthening of demand that will produce faster growth of output in the current year. With it may come some increase in inflation, not only in those countries like Ireland and Spain that are already growing rapidly but also in the core countries like Germany and Italy. 
The ECB's ability to maintain low inflation in the long term will depend on whether its members can avoid political pressure to overexpand demand. During the past two decades the countries of Europe have brought down their inflation rates because a failure to do so would have meant the embarrassment of having to devalue relative to the German mark. That discipline will no longer be there in the future in a system in which there is no German mark and in which each country in the EMU has a vote on monetary policy. As I look ahead, I think it is likely that inflation will rise in Europe and that the increase will be greater because of the euro than it would otherwise have been.

\section{Not an Appropriate Currency Area}

The experience of the past year has already made it clear that the euro zone is not an appropriate territory for a currency union, i.e., is not an optimal currency area. In 1999, demand conditions in Germany and Italy were relatively weak while demand conditions in Spain, Portugal and Ireland were very strong. The result was a substantial acceleration of inflation in both Spain and Ireland that threatens their competitiveness and therefore the longer term success

of the industries that have helped them prosper in recent years. Such disparities of demand conditions will undoubtedly persist in the future because individual countries differ substantially in industrial composition and in a variety of economic policies that cause their cyclical conditions to differ.

As Robert Mundell taught us many years ago, a single currency is appropriate in an area where labor and product markets are flexible, where labor is mobile among regions within the area, and where a central fiscal authority automatically provides counterbalancing fiscal transfers. These conditions are satisfied in the United States but not in Europe. European wages are very 
inflexible. Labor's mobility is severely limited by barriers of language and custom even if legal barriers are no longer present. And there is no significant fiscal transfer to compare to the roughly 40 percent offset that US taxes and transfers achieve.

The ECB must make monetary policy for "Europe as a whole" which basically means for a weighted average of the European economies. This in turn is likely to mean making the monetary policy that is appropriate for Germany, France and Italy. In 1999 that meant a policy that was too expansionary for Spain, Portugal and Ireland. The OECD has warned these countries that they are allowing demand to grow too rapidly. They are now in violation of the Maastricht principle that the inflation rate of each country must not exceed the average of the lowest three countries by more than 1.5 percent. But, with no ability to adjust monetary policy, there was little that they could do other than adopt tight fiscal policies that would have been politically unpopular and that could have adverse incentive effects.

In short, "one size fits all" monetary policy is not appropriate for the eleven countries of the Economic and Monetary Union and it will be even less appropriate as the EMU expands to include many more countries in the coming years.

\section{Three Counterarguments}

The supporters of the EMU and the single currency often acknowledge these disadvantages of imposing a single monetary policy on a variety of separate countries but argue that the result is preferable to the poor monetary policies that would otherwise be adopted by the smaller countries if left to do so on their own. I do not find this association of small countries with bad monetary policies at all convincing. Switzerland has had even lower inflation than Germany during recent decades. Ireland's monetary and tax policies gave it the strongest rate of 
real growth in Europe with little inflation. Other small countries like the Netherlands and Austria chose to tie their currencies to the German mark for many years before the introduction of the euro while retaining the ability to break that link if external conditions made it advisable. And not that many years ago the United States followed a monetary policy that allowed our inflation rate to rise to double digit levels.

It is also hard to understand why one should believe there is likely to be greater wisdom about monetary policy in a committee of country representatives than in a system that places responsibility for domestic inflation with the domestic central bank.

A further argument of some of the defenders of the single currency is that it will bring Anglo-American style equity markets to continental Europe, with the resulting benefits of the increased discipline that results from focusing on shareholder value and on the efficient use of capital. Such a change in equity markets may well happen in Europe. But there is no reason to attribute such a change to the adoption of the euro. The Japanese are beginning to move in that direction for very different reasons. The shift to a system of funded corporate pensions in Europe in order to cope with the ageing of the population will create a demand for equities that will shift corporate ownership from the banks to financial markets. More generally, the evidence on the advantages of a market based equity system of the type seen in the US and the UK, rather than a system of bank ownership or privately held companies that is characteristic of much of continental Europe, is a powerful enough force to cause that to happen with our without a single currency.

Finally it is argued that EMU is to be praised for its success in reducing fiscal deficits. It is certainly true that the Maastricht treaty required lower deficits and national debt as a condition 
for a country's admission to the Economic and Monetary Union. Some countries achieved this by accounting tricks and intra-year movements of spending and tax receipts or by treating asset sales as if they were a real source of revenue for the government. Some countries just failed to come close to the debt-to-GDP targets but were allowed to overlook there failure to meet the conditions on the grounds that their debt ratios were moving in the right direction.

Much of the apparent reduction in the fiscal deficits occurred because interest rates paid on the national debt came down sharply as inflation expectations improved. This in turn means that the reductions in the nominal deficits do not imply corresponding reductions in the real deficits, i.e., in the national debts adjusted for the expected inflation erosion of those debts.

What matters however is not the extent to which deficits fell in the process of gaining EMU entry but the effect of the EMU on the size of the future deficits. A very important effect of the single currency is that a country's interest rate is no longer a signal of the market's concern about the magnitude of that country's deficits. Although countries can face different interest rates because of differences in apparent credit worthiness, this market signal will be blurred in practice by the assumption that the EMU will not let any member country default on its debt. It is the fear of such fiscal profligacy that caused the members of the EMU to adopt the so-called Stability Pact that limits the size of a country's permissible deficit and states that countries will be penalized financially if they violate these fiscal norms. It remains to be seen whether such penalties will actually be levied in practice and whether countries will actually borrow less (i.e., have smaller budget deficits) when they have a single currency that permits them to borrow elsewhere in Europe more easily than they could before the beginning of the EMU. 


\section{Unemployment and Trade Protectionism}

It was lucky for the euro that in its first year the outlier countries were enjoying very strong growth rather than high cyclical unemployment. But the time will come when the ECB will set a policy that is too tight for the outlier countries, forcing them to have substantially higher unemployment rates than they would have chosen if they were free to set their own monetary policy. Indeed, even without discretionary monetary policies, the interest rates in countries with weak demand would naturally decline and the external value of their currencies would also fall, both acting as offsetting stabilizers of the country's weak demand. But this will not be possible within the EMU where a single risk-adjusted interest rate and a single exchange rate prevail.

I predict that over time the EMU will therefore bring a higher level of cyclical unemployment than would be possible in a Europe of separate national currencies. Moreover, I believe that a sustained period of high cyclical unemployment in any country will lead some of its politicians to turn against their European neighbors for their lack of compassion. I will return to this problem of political conflict.

Most of the high unemployment in Europe now is not cyclical but structural, reflecting bad welfare policies, bad regulations, and high taxes. The ability to solve these problems should be separate from the monetary arrangement. And yet I suspect that EMU will reduce the likelihood that countries will solve these structural problems. It will be easier for politicians to point to the ECB as a powerful force beyond national control that is keeping interest rates too 
high and thereby maintaining high unemployment. Mr. Lafontaine was not successful when he tried that line of argument. But there will be others who may be more successful in the future, especially in countries that lack Germany's support for low inflation and for an independent central bank.

Some of the defenders of the euro have argued that although Europe is not currently an appropriate zone for a single currency, it will evolve into one as a result of adopting a single currency. Although that might eventually be true, there is no evidence of it in this first year and no reason to believe that the future will be better. Certainly there has been no progress in making labor markets more flexible. Instead we hear more and more about social wages, about 35 hour maximum work weeks, and about rolling back even the small reductions in social benefits that had been achieved in Germany by the Kohl government. Worse yet there are attempts attempt to eliminate differences in labor practices and even differences in wages among the EMU countries.

The result of all of this will be not only to make Europe less suited to a single currency but also to exacerbate the structural problems that keep unemployment so high. Moreover, I fear that these counterproductive policies will reduce the international competitiveness of many European industries and encourage the adoption of protectionist policies to keep non-European products out of European markets. If labor standards and environmental regulations become acceptable subjects for discussion in the context of international trade, it would not be difficult to imagine Europeans arguing that they should not have to complete with American firms that do not provide the European-level social benefits to their employees, have longer working hours, and follow practices that are less friendly to the environment.

An inward looking Europe that sees itself as more self-contained politically and 
economically could easily move in this direction. The European objection to American genetically engineered agricultural products and the French unwillingness to import British beef may be early signs of future protectionism and trade conflicts.

\section{Political Effects and Potential Conflicts}

It is thus hard for even a European to love the euro for its potential economic effects. It is more understandable to regard the euro as an economically costly device for achieving political union. Political advocates of the euro may believe that individuals who carry euros in their pockets will come to think of themselves as Europeans and that this will reduce the risk of a recurrence of the intra-European wars that have done so much harm during the past century and half. Perhaps. But I think it is more likely that the attempt to achieve Europe-wide policies will in itself be a major source of conflict within Europe and with the United States. The existence of a single currency, and even of a relatively centralized fiscal system, does not guarantee harmony among the geographic regions, as the experience of the U.S. civil war made clear.

Forcing a single monetary policy on all of Europe will cause those countries that suffer what they regard as unnecessarily high unemployment to resent the actions of others. Tax policies are another potential source of economic conflict. Although tax policies are now left to national governments, that will not continue indefinitely as attempts at "tax harmonization" eventually succeed and provide the platform for seeking greater uniformity in tax rates and tax bases. Attempts to force a Europe-wide tax system on all countries will be a further source of conflict. To the extent that those taxes are used to redistribute incomes among European countries, the potential for conflict will be even greater. 
The Maastricht treaty that created the Economic and Monetary Union makes no provision for a country to leave the EMU and return to its own currency. While a country might nevertheless unilaterally opt to leave, it would risk being denied all of the trade benefits of the single market and might face other forms of retribution. EMU is meant to be a marriage made in heaven with no room for divorce.

One way for European governments to overcome the intra-European conflicts and to create greater unity within Europe is to have a common adversary. The Soviet Union, which played that role for the past half century, no longer exists. Today's Russia is not the threat that the Soviet Union once was. I worry that the United States will come to be seen as a politically convenient adversary, an adversary that can be used to permit the European agenda of political and economic unification to advance despite the tensions that it creates among the countries of Europe.

Which brings me back to my initial comment that the successful launch of the euro is something to be noted but not something to be celebrated.

Cambridge, MA

January 25,2000

Revised 